\title{
Social representations of comfort for patients' family members in palliative care in intensive care
}

\author{
Representações sociais de conforto para familiares de pacientes \\ em cuidados paliativos na terapia intensiva \\ Representaciones sociales de confort para familiares de pacientes \\ en cuidados paliativos en cuidados intensivos
}

\author{
Odisséia Fátima Perão \\ Eliane Regina Pereira do Nascimento ${ }^{b}$ \\ Maria Itayra Coelho de Souza Padilha ${ }^{b, c}$ \\ Daniele Delacanal Lazzarib \\ Patrícia Madalena Vieira Hermida ${ }^{d}$ \\ Mayara Ana da Cunha Kersten ${ }^{a}$
}

\begin{abstract}
How to cite this article: Perão OF, Nascimento ERP, Padilha MICS, Lazzari DD, Hermida PMV, Kersten MAC. Social representations of comfort for patients' family members in palliative care in intensive care. Rev Gaúcha Enferm. 2021;42:e20190434. doi: https://doi. org/10.1590/1983-1447.2021.20190434
\end{abstract}

a Universidade do Vale do Itajá (UNIVALI), Escola de Ciências da Saúde. Departamento de Enfermagem. Itajaí, Santa Catarina, Brasil.

' Universidade Federal de Santa Catarina (UFSC), Centro de Ciências da Saúde. Programa de Pósgraduação em Enfermagem. Florianópolis, Santa Catarina, Brasil.

c Universidade Federal de São Paulo (UNIFESP), Escola Paulista de Enfermagem. São Paulo, São Paulo, Brasil.

${ }^{d}$ Prefeitura Municipal de Florianópolis, Secretaria Municipal de Saúde. Florianópolis, Santa Catarina, Brasil.

\section{ABSTRACT}

Objective: To know the social representations of comfort for patients' family members in palliative care in intensive care. Method: Descriptive, qualitative study, theoretical framework adopted was Social Representations. 30 family members of patients admitted to an intensive care unit in palliative care participated. Data were collected through semi-structured individual interviews, organized and analyzed using the Collective Subject Discourse technique.

Results: Pointed out as central ideas, positive and negative feelings of family members, communication and interaction with the team, ICU as excellence and palliative care as a measure of comfort for the patient and the family.

Conclusion: The social representations about the comfort of family members of hospitalized patients in an intensive care unit in palliative care are identified by the family members' feelings during the visit, communication, and the humanized care applied by nursing professionals in the patients in palliative care.

Keywords: Palliative care. Intensive care units. Patient comfort. Family. Nursing.

RESUM0

Objetivo: Conhecer as representações sociais de conforto para familiares de pacientes em cuidados paliativos na terapia intensiva. Método: Estudo descritivo, qualitativo, referencial teórico adotado foi Representações Sociais. Participaram 30 familiares de pacientes internados em unidade de terapia intensiva em cuidados paliativos. Os dados foram coletados por meio de entrevistas individuais semiestruturadas, organizados e analisados por meio da técnica do Discurso do Sujeito Coletivo.

Resultados: Apontaram como ideias centrais, sentimentos positivos e negativos dos familiares, a comunicação e a interação com a equipe, a UTI como excelência e o cuidado paliativo como medida de conforto para o paciente e a família.

Conclusão: As representações sociais sobre o conforto dos familiares de pacientes internados em unidade de terapia intensiva em cuidados paliativos estão identificadas pelos sentimentos dos familiares durante a visita, comunicação, e o cuidado humanizado aplicado pelos profissionais de enfermagem nos pacientes em terapia paliativa.

Palavras-chaves: Cuidados paliativos. Unidades de terapia intensiva. Conforto do paciente. Família. Enfermagem.

\section{RESUMEN}

Objetivo: Conocer las representaciones sociales de confort para familiares de pacientes en cuidados paliativos en cuidados intensivos. Método: Estudio descriptivo, cualitativo, se adoptó el marco teórico de Representaciones Sociales. Participaron 30 familiares de pacientes ingresados en una unidad de cuidados intensivos en cuidados paliativos. Los datos fueron recolectados a través de entrevistas individuales semiestructuradas, organizadas y analizadas utilizando la técnica del Discurso del sujeto colectivo.

Resultados: Señalados como ideas centrales, sentimientos positivos y negativos de los miembros de la familia, comunicación e interacción con el equipo, UCI como excelencia y cuidados paliativos como medida de confort para el paciente y la familia.

Conclusión: Las representaciones sociales sobre la comodidad de los miembros de la familia de los pacientes hospitalizados en una unidad de cuidados intensivos en cuidados paliativos se identifican por los sentimientos de los miembros de la familia durante la visita, la comunicación y la atención humanizada aplicada por los profesionales de enfermería en los pacientes en cuidados paliativos. Palabras clave: Cuidados paliativos. Unidades de cuidados intensivos. Comodidad del paciente. Familia. Enfermería. 


\section{口INTRODUCTION}

Palliative care is a philosophy of care that aims to improve the quality of life of individuals and family members in the presence of chronic and degenerative diseases, reiterating life and death as natural processes. With the increase in life expectancy and the reduction in the number of deaths from communicable diseases, the document published in 2004 by the WHO entitled The solid facts - Palliative Care, reinforced the need to include palliative care as part of complete health care ${ }^{(1)}$. This concept permeates around the family, team and caregivers who assist patients in palliative therapy.

Additionally, this perspective is recognized by the World Health Organization (WHO), which defines palliative care as care practices developed by an interdisciplinary team, with the aim of improving the quality of life of patients and their family members through prevention and relief suffering, early identification of possible situations to be treated, careful evaluation and treatment of pain and other physical, social, psychological and spiritual symptoms ${ }^{(2)}$. Palliative care can be applied at home level, in clinics, in the hospital environment and also in intensive care units (ICU).

A study that aimed to identify predictors of death in the ICU and to relate patients eligible for preferential palliative care, demonstrates that a portion of patients who are admitted to the ICU would need a palliative assessment and approach from the moment of their admission, so that therapeutic limits can be established and avoid false hopes for family members and the team that assists this patient ${ }^{(3)}$. The practice of palliative care performed in team, with a multidisciplinary and interdisciplinary character is the result of an approach focused on the human being in its entirety, aiming to satisfy the needs of a physical, social, emotional and spiritual nature ${ }^{(1)}$. In addition, palliative care in intensive care units requires specific professional skills from the team, both to meet the needs of patients and family members. Considering that patient, family and interdisciplinary team, regardless the level of health care, are part of the fundamental pillars of palliative care, it is fundamental the interaction of the subjects to build care that aims to improve the quality of life.

In the hospitalization process of a terminally ill patient, the impact of a serious illness can be a precursor to changes in the family structure. A study carried out in an ICU in the state of Ceará found that there were changes in the family context of patients in palliative care, highlighting: financial expenses, non-adaptation to the hospital routine, the need to spend a lot of time following patients, and personal projects , such as study and formal work that are in the background ${ }^{(4)}$. These changes can alter the comfort of the patient's family member admitted to an intensive care unit in palliative care.
It is noted in the literature the existence of the meaning of comfort for people in the ICU, however, under the focus of family members, there are few studies, especially with regard to the comfort of patients'family members admitted to the ICU in palliative care ${ }^{(5)}$.

It is known the existence of several concepts and constructs about the comfort object in the literature, however, in this study, comfort is used as a multidimensional phenomenon that includes feelings of improvement, security of own care, or professional that results in the restoration of personal strength and power, permeating the physical, psychological, social, spiritual and environmental spheres, linked to time and space ${ }^{(6)}$. In addition, comfort comes in three types: relief comfort, resulting from a specific answered need; ease in comfort, a state of calm or satisfaction; and transcendence, a state of being in which problems or pain can be overcome ${ }^{(6)}$. Simultaneously with the theoretical framework of the study, the choice of these concepts is made, since in its complexity, it favors better visibility of the object, to the research subject.

The Social Representations Theory (SRT) is used as a theoretical framework due to the high potential to elucidate the meanings that are produced and shared in groups, predominantly, in this case, family members of admitted patients in an intensive care unit in palliative care. The SRT seeks to conceptualize the social reality and the performance of the subjects, being a link between the real, the psychological and the social, being able to establish connections between the abstract life, the knowledge, the beliefs and the concrete life of the individuals. Thus, social representations include the construction of meanings about the social environment, guide the conduct of social subjects and model the social environment in which behavior is reproduced (7).

Making use of this theory, the comfort here presented results from the interaction of ideas, values and concepts, demonstrated by the family members of patients in palliative therapy in an intensive care unit, concepts that are needs arising from the knowledge demonstrated by the family member in a given circumstance and time, and may suffer modifications according to the reality and space in which it is inserted.

The realization of this study is justified by the need to understand the social representations of the comfort of family members, in order to provide adequate assistance, aiming at improving the quality of life, breaking paradigms and bringing the family member closer to the care provided to their loved one. Unfortunately, in some intensive care units, the family member is not seen as an integral part of the care and the family members' concerns and questions favor the distancing of the team with the family. In this context, are 
questioned the social representations about comfort for the family members of adult patients under palliative care admitted to the intensive care unit.

Therefore, the study has as objective to know the social representations of comfort for patients' family members in palliative care in intensive care.

\section{METHODS}

This is a descriptive study with a qualitative approach and supported by the Social Representations Theory ${ }^{(7)}$.

The study scenario was an ICU of a hospital institution located in Florianópolis - Santa Catarina.

Data collection occurred between July 2016 and December 2017, through semi-structured individual interviews, guided by a script with questions about the meaning of the ICU for the family member, how he felt when visiting the relative in the ICU, from how he wanted to be treated, and what he thought about palliative care. The interviews were conducted according to the availability of the participants in a room reserved in the sector itself, and some in the family members'home, as agreed between the researcher and the interviewed. With an average of 30 minutes, the interviews were recorded. To guarantee anonymity, participants were identified by the letter $F$ (family) followed by Arabic numbers corresponding to the order of the interviews (F1 to F30).

Participated 30 family members of patients admitted to the ICU under palliative care who met the following inclusion criteria: age equal to or above 18 years old, being the closest family member to the patient and having their family member admitted to the ICU with more than 48 hours of hospitalization under palliative care. In this study, the closest family member was the person who maintained a close relationship with the patient, regardless of blood ties, and at the time of collection, he was aware of the therapeutic conduct applied to his hospitalized family member.

It was used as a criterion to the end of the interviews the saturation of the information provided by the participants, that is, there were no new elements, and new interviews were unnecessary, as the understanding of the phenomenon studied remained unchanged.

After the interviews, it was proceeded with the transcription of the participants speeches in complete, and in the search for the understanding of the intentional acts and the essences of each family member interviewed, aiming to achieve the proposed objective of the study. For the analysis and treatment of the data, it was used the Collective Subject Discourse (CSD) method, a methodology based on the Social Representation Theory. Its use in qualitative researches allows to reveal the thoughts, representations, values and beliefs of a community about a given theme, using scientific methods ${ }^{(8)}$. In this study, it was to know the social representations of comfort for patients' family members in palliative care in intensive care.

The CSD methodological figures were evidenced: 1) Key Expressions (KEs) are excerpts from the speech that should be highlighted by the researcher, and that reveal the essence of the speech content; 2) Central Ideas (Cls) are words that express the meaning(s) present in each of the analyzed responses; and 3) Collective Subject Discourses (CSDs), originated from $\mathrm{Cls}$, which are the aggregation, or sum of the statements of the research subjects. Anchoring (AC), also considered a methodological figure, was not revealed in this study, since it is characterized by explicit linguistic features of the subject's belief expression and which are internalized in $i t^{(9)}$. The collected data were processed and organized with the support of DSCsoft software version 1.3.0.0.

As it is a study involving human beings, it complied with the legal provisions contained in Resolution 466/2012 of the National Health Council, beginning after the appreciation and approval of the Research Ethics Committee of the Universidade Federal de Santa Catarina, by statement No.1,599,470. Study participants were duly informed about the purpose, proposed objectives, confidentiality of information and ensuring the preservation of anonymity.

\section{$\square$ RESULTS AND DISCUSSION}

The interviewed family members were aged between 25 and 75 years, and the majority were female $(n=19 ; 63.3 \%)$. Regarding the degree of kinship, children ( $n=9 ; 30 \%)$ stood out, followed by husbands ( $n=6 ; 20 \%$ ) and wives ( $n=6 ; 20 \%)$ and the others were partners, mother, sister, brother and father $(n=9 ; 30 \%)$. Regarding the level of education, family members with a complete primary education $(n=10 ; 33.3 \%)$ stood out and an equal number of complete secondary education ( $n=10 ; 33.3 \%)$. Only one family member reported having completed third grade $(n=01 ; 3.3 \%)$. Regarding religion, family members were Catholic $(n=18 ; 60 \%)$, evangelical $(n=9 ; 30 \%)$ or had another religion $(n=03 ; 10 \%)$. Most interviewed were employed, and some family members had another experience of a relative hospitalized under palliative therapy in the ICU ( $n=07 ; 23.3 \%)$.

The prevalence of female relatives has also been observed in other studies, although men are also identified as present and participating in intensive care units ${ }^{(5,10)}$. Despite the modernity in which we live, in which pragmatic ideologies try to be left aside, women still have greater responsibility about the care and compassion to others. Regarding the degree of kinship, husband and wife together constitute 
a major population in relation to sons, brothers or other degree of kinship, discerning from a study that there was a predominance of sons or daughters ${ }^{(5)}$.

Regarding to schooling, family members with a complete primary education stood out and the predominant religion is Catholic. The findings are in accordance with the $2010 \mathrm{Bra}-$ zilian Institute of Geography and Statistics (Instituto Brasileiro de Geografia e Estatística - IBGE) census, according to which only 7.9\% of Brazilians have a higher education level and $64.6 \%$ of Brazilians are Catholics. Most family members have paid work. Considering that the female gender is prevalent in this study, it is worth mentioning the work overload of women, which exceeds that of men in almost five hours ${ }^{(11)}$. Thus, it can be inferred that the hospitalization process favors socioeconomic changes, as the family member is absent for a longer period of paid activity when visiting his loved one.

An important result detected in this study is related to the family member's previous experiences - having or not having another relative admitted to the ICU in palliative therapy. In this study, only 10 family members have had relatives admitted to the ICU with this condition. The fact of having experienced another hospitalization of a relative in the ICU does not exempt the person from feelings and anguish in the face of the new reality. The multiple feelings during the visit to the loved one in the ICU are inherent to the human being who experiences changes in the family environment, mainly due to the process of human finitude. A common phenomenon for family members of end-of-life patients in the ICU is anticipatory mourning.

The mourning experienced in this case differs from that resulting from a sudden loss, due to its slow and gradual form, depending only on time, and to the fact that the person to whom the cause of the mourning falls is still alive ${ }^{(12)}$. It seems that at all times we are living experiences of loss, abandonment and the desire to give up, conditions inherent to life. Grieving, therefore, is a course of changing situations in which we all live. However, it is clear that it is still a process that is considered painful, difficult and slow.

The Central Ideas of social representations about comfort for patients' family members of undergoing palliative treatment in the intensive care unit are shown in Table 1.

There was highlight on communication and interaction with the team, the ICU as excellence in care and the comfort measures that emerged from the statements of all participants. Social representations of positive feelings were less shared among family members than negative ones.

Below is the Central Ideas with the Collective Subject Discourses.

CSD 1 - When I enter the ICU to visit my relative, several thoughts and feelings cross my mind. The environment scares me. In the same place I see people crying and others smiling. Sometimes I feel pain, a lot of sadness, fear, insecurity, I feel powerless because I can't do more. I get disoriented, I don't know if I can touch him anymore. My feelings are of loss, frustration, anguish, after all, I am not prepared for the loss. There are nights that I don't sleep, thinking that anytime they can call me, giving me the bad news. It seems that nothing comforts me, I don't know how to be alone. I wish I could stay with him for longer. When I leave, it feels like l'm leaving a part of me here. (F1, F2, F3, F4, F5, F7, F8, F9, F10, F12, F14, F15, F16, F17, F19, F20, F21, F23, F24, F25, F26, F27, F29, F30)

Table 1 - Central Ideas on comfort for patients'family members in palliative care at the ICU, Florianópolis, Santa Catarina, 2018

\section{Central Ideas}

Central Idea A: Negative feelings during the visit

Central Idea B: Positive feelings during the visit

Central Idea C: Communication and interaction with the team

Central Idea D: ICU as excellence in care

Central Idea E: Palliative care as comfort measures for the patient and family

\section{$\mathbf{N}$}

24

12

30

30

30
$\% *$

80.0

40.0

100.0

100.0

100.0

Source: The authors, 2018

* Relative frequency according to the total number of interviewed for presenting the same central idea] 
In this discourse, negative feelings are evidenced during the visit of patients' family members admitted to the ICU under palliative care, feelings such as pain, fear, sadness, insecurity, anguish, loss, frustration and loneliness, feelings that are inherent to the human being. The belief system, the socio-cultural values, life history, bond style and affective bond are related to the way of coping with the loss, experienced by the patient's family member in palliative care in the intensive care unit. It is essential that the ICU health team is prepared to soften the negative feelings of family members, through actions that facilitate comfort, and consequently will result in a state of calm and satisfaction for family members. The CSD1 can be represented as a "seven-headed-beast", which in its subjectivity expresses all the complexity experienced by the family member through the patient's hospitalization in palliative therapy in the ICU.

However, in Central Idea B, there are positive feelings of hope, peace, faith, tranquility, and comfort, as described in CSD2.

CSD2 - I have hope, faith in God, even though I know that his condition is irreversible, because they have already warned me of gravity. I feel peace of spirit when I see my family member breathing without agony. I feel calm, thank God. I believe that he is not suffering, it seems that he is comfortable, and this gives me a feeling of relief and I feel comfortable. I see the team's dedication and work so that he doesn't suffer and I realize that the team is prepared to deal with difficult situations, [...] I would not have that courage. (F1, F6, F10, F11, F12, F13, F14, F18, F20, F22, F28, F29)

The feeling of faith, in its subjectivity, can strengthen family members in facing anticipatory mourning from a palliative perspective. In view of the difficulties, some family members look in spirituality for strength to better understand the hospitalization of their loved one and their health status. When the family member knows the care that is being instituted for their loved one, they more easily adhere to palliative therapy. Consequently, their sufferings will be softened, so that feelings such as comfort, peace and tranquility will be perceived. Spirituality is also a factor to the harmony of the interdisciplinary team, it is an important therapeutic resource, as it provides comfort, whether through prayer made together with the patient and relative, or even individually, always in favor of the binomial patient and family ${ }^{(13)}$.

Another relevant aspect in CSD2 is the reciprocity of care applied to the patient, reflected in a feeling of relief and comfort to the family member. Care is conceived as something that is part of human life, in response to human needs, since the dawn of humanity. When health professionals are attentive to these needs, in their most diverse forms of illness, they will be able to relieve the suffering of the family member and the loved one, resulting in an improvement in the quality of life. Analyzing the CSD1 and CSD2, the expression of feelings in all their fullness emerged as a social representation of comfort, being able to influence directly or indirectly in care.

However, communication and interaction with the team must be considered so that care is applied in its entirety, bearing in mind that this theme emerged as Central Idea C, from the discourse of family members (CSD 3 ).

CSD 3 - I always had good reception and good service by professionals, as they treat me with respect. Some are serious, others more sympathetic. I would like to be able to talk more with the ICU team and that the visit time be longer. I would also like to express my feelings, I miss that exchange. I don't know if my presence gets in the way of the team's work. The doctors have already told me about the severity of my relative, but I wanted to have more information, if I can help with treatment in any way. When l ask a question to the nursing team about the treatment of my relative, they answer me to wait for the bulletin and talk to the doctor. There could be more dialogue between family members and the ICU team. (F1, F2, F3, F4, F5, F6, F7, F8, F9, F10, F11, F12, F13, F14, F15, F16, F17, F18, F19, F20, F21, F22, F23, $F 24, F 25, F 26, F 27, F 28, F 29, F 30$ )

Communication, when used properly, is an excellent work tool in care, as it promotes greater interaction between the team and the person being assisted, facilitating the creation of bonds of trust and obtaining greater satisfaction from patients and team who provide the service ${ }^{(14)}$. The collective subject of this study hopes to establish a clear, honest and accessible communication with the health team in the ICU.

However, the lack of information about the patient's clinical status, routine and short visit times in the ICU, interfere in the comfort and satisfaction of family members, since comfort encompasses social and environmental dimensions. The information transport is an element of social comfort and the visiting hours routines are elements of environmental comfort. The implementation of an open visit, that is, the family member be able to visit their loved one in the ICU at any time of the day, is a reality already established in some services in Brazil and in the world, but which needs support from the professionals involved in the care process. The ideal would be the implementation of different times for visits to patients in palliative care. 
The family member, during the visit in the ICU, when asking the nursing team about the situation in which his ill family member is, besides being waiting for an answer, believes he wants attention and a closer relationship with the team. Unfortunately, for some professionals there is a lack of empathy and the distance between the nursing team and the family is observed, especially during visiting hours, although nursing has a greater facility for creating bonds, since it is closer to the patient and the family, visualizing the needs presented ${ }^{(15)}$.

The presence of a multidisciplinary team member such as nursing technicians, nurses and physiotherapists at the bedside, close to the family member, provides the patient and family not only a feeling of security and welcome, but also makes them more comfortable to question about the doubts that arise from hospitalization ${ }^{(16)}$. An ethnographic study with ICU nurses pointed out to unpreparedness and the inability to deal with life processes, including comfort and family. They believe that the development of this skill will require adaptation in the professional training process ${ }^{(17)}$. Thereby, communication is a social representation of comfort for patients'family members admitted to the ICU under palliative care, as long as it is efficient and there is the interaction of those involved in the care process. Thus, the communication portrayed in the psychosocial context of comfort, perpetuates a harmonious relationship between the health team and patients'family members in palliative therapy.

Regarding the meaning of ICU, expressed by Central Idea D "ICU as excellence in care", there is an ambivalence in the sense of ICU as a place to save lives and at the same time a place attributed to death.

CSD4 - The ICU for me is a place for very serious people, who cannot be treated in the clinics or elsewhere in the hospital. It means reviving/resuscitating patients. I know that some manage to get out of the ICU, manage to recover, but most are not so lucky. It means a place of well-trained and capacitated professionals, who must be agile and know the equipment with which they work. Unfortunately, my family member, even being in the ICU, will not be able to save himself, his case is very serious, but I know they are doing their best for him. I realize that professionals seek to carry out the best treatment conduct for each patient, so the ICU is the best place of care in the hospital. (F1, F2, F3, F4, F5, F6, F7, F8, F9, F10, F11, F12, F13, F14, F15, F16, F17, F18, F19, F20, F21, F22, $F 23, F 24, F 25, F 26, F 27, F 28, F 29, F 30$ )
This result was also observed in a study of social representations with patients'family members in the ICU, in which $80 \%$ of interviewed associated the same idea of death and $20 \%$ related it as a place of care that offers greater security for health recovery ${ }^{(17)}$. Another relevant factor observed in CSD4 discourse the trust placed in the ICU team, as it is a trained and prepared team that works in an environment with technological devices. However, the integrality of care, in its humanistic aspects, must override technological practicality. In this sense, improving the knowledge of the professionals who compose the multidisciplinary team in the ICU about palliative care and the acquisition of skills inherent in this care are important tools for promoting quality of life and sustaining comfort.

In Central Idea E, "Palliative care as comfort measures for the patient and family", CSD5 is the empirical result of the family's understanding about palliative care.

CSD5 - I didn't quite understand what this palliative care was. According to what was talked with the doctors, I understood that there is no more to be done with my family member, there is no more medication or other resources to cure him, only comfort care, which must be these palliative care. I understand that palliative care is not letting my family member suffer more than he has already suffered with so many procedures that have already been done with him. Keeping him sedated can also be part of palliative care, because he does not deserve to be in pain. When I see him like this, without pain, I feel calm, because I know he will not suffer when the time comes to rest. I know that palliative care will not cure him, but it can reduce suffering. When I see ICU professionals taking care of my family member with respect, I believe that it is also palliative care. They try to make him very comfortable, massage him, handle him carefully, so as not to hurt him, they are always attentive to the numbers that appear on the monitor. I believe that with palliative care, my family member will have a more peaceful death, without suffering, with more comfort, with trained professionals for this care. The important thing for me is not to see him suffering. It is seeing him being well taken care by the medical team, nursing, by everyone who works in the ICU, so I feel more relieved, I go home calmer. (F1, F2, F3, F4, F5, F6, F7, F8, F9, F10, F11, F12, F13, F14, F15, F16, F17, F18, F19, F20, F21, F22, F23, F24, F25, F26, F27, $F 28, F 29, F 30)$ 
It is highlighted cessation of pain as a measure of comfort. Considering that providing relief for pain and other stressful symptoms is one of the principles of palliative care established by the World Health Organization, it should be directed the performance of the multidisciplinary team that needs to be trained, in order to be able to assist the patient and the family in their entirety. Research with ICU nurses revealed that when patients are in end-of-life situations, most of the time they direct care to relieve pain and suffering with analgesia and sedation, dressing, allowing visits and change of decubitus ${ }^{(18)}$. Comfort measures in the ICU, reflected in daily care, are the result of humanized care aimed at improving the patient's quality of life in palliative and family care. However, it is worth emphasizing the importance of the role of nurses in welcoming, communicating and other actions, guided by ethical principles, providing efficiency in promoting comfort ${ }^{(19)}$.

The humanized care applied by nursing professionals to patients undergoing palliative therapy in the perception of the family member, in this study, results as a social representation about comfort.

\section{Q CONCLUSION}

Social representations of comfort for patients' family members under palliative care in the ICU were identified by negative and positive feelings, communication and humanized care. Feelings should be given more specific attention, with a look at the biological, social and spiritual spheres, in order to transcend comfort in its entirety.

The discourses analysis can show that communication is fundamental to the applicability of palliative care, and as a social representation of comfort, directly interfere in the patient, family, and team relationship, when not performed efficiently. In this representation, the implementation of the open visit in the ICU was a fact that was unveiled.

In the view of family members, the ICU as excellence demonstrates the social representation of comfort, in which the family and patient are inserted in an environment that has a trained nursing team and multiprofessionals who are able to handle an arsenal of technological devices with safety and confidence. Palliative care as comfort measures are the result of family members' understanding about the concept of palliative care, with a focus on humanized care for their loved one.

These inferences suggest the construction of strategies focused on the comfort of the family member, of patients in palliative care, instituted by the ICU multiprofessional team, emphasizing communication and the process of interaction of family, patient, and team. It is also suggested to implement an open visit in the ICU, especially for patients' family members in palliative care.

As a limitation, it is highlighted the fact that it was carried out with patients' family members in palliative care of only one ICU, evidencing the social representations of the comfort of a single studied reality. It was observed a gap in the literature when looking for specific articles about the comfort of family members in an intensive care unit in palliative care, which instigates the construction of new studies on this topic.

\section{REFERENCES}

1. Gomes ALZ, Othero MB. Cuidados paliativos. Estud Av. 2016;30(88):155-66. doi: https://doi.org/10.1590/s0103-40142016.30880011

2. Worldwide Palliative Care Alliance (UK). Global atlas of palliative care at the end of life 2014. London: WPCA; 2014 [cited 2019 Mar 10]. Available from: https:// www.who.int/nmh/Global_Atlas_of_Palliative_Care.pdf

3. Gulini JEHMB, Nascimento ERP, Moritz RD, Vargas MAO, Matte DL, Cabral RP. Predictors of death in an intensive care unit: contribution to the palliative approach. Rev Esc Enferm USP. 2018;52:e03342. doi: https://doi.org/10.1590/ S1980-220X2017023203342

4. Lima MP, Oliveira MCX. Significados do cuidado de enfermagem para familiares de pacientes em tratamento paliativo. Rev Rene. 2015 [cited 2015 Dec 18];16(4):593-602. Available from: http://www.revistarene.ufc.br/revista/ index.php/revista/article/view/2112/pdf

5. Kolcaba K. Comfort theory and practice: a vision for holistic health care and research. New York: Springer; 2003.

6. Valente CO, Fonseca GM, Freitas KS, Mussi FC. Conforto familiar a um parente internado na unidade de terapia intensiva. Rev Baiana Enferm. 2017;31(2):e17597. doi: https://doi.org/10.18471/rbe.v31i2.17597

7. Moscovici, S. Representações sociais: investigações em psicologia social. 11. ed. Petrópolis: Vozes; 2015.

8. Oliveira SX, Oliveira MD, Camboim FEF, Nóbrega MMS, Lima AB, Melo AC. Teorias das representações sociais e o discurso do sujeito coletivo como ferramentas para 0 desenvolvimento de pesquisas qualitativas. Temas Saúde. 2018 [cited 2019 Mar 15];(esp):126-35. Available from: http://temasemsaude.com/wpcontent/uploads/2018/10/fip201808.pdf

9. Lefreve F, Lefreve AMC. Pesquisa de representação social: um enfoque qualiquantitativo: a metodologia do Discurso do Sujeito Coletivo. 2. ed. Brasília: Liber Livro; 2012. p. 224.

10. Dotolo D, Nielsen EL, Curtis JR, Engelberg RA. Strategies for enhancing family participation in research in the ICU: findings from a qualitative study, J Pain Symptom Manage. 2017;54(2):226-30. doi: https://doi.org/10.1016/j. jpainsymman.2017.03.004

11. Instituto Brasileiro de Geografia e Estatística [Internet]. Rio de Janeiro: IBGE; c2010-2020 [cited 2018 Fev 15]. Censo 2010 [about 1 screen]. Available from: https://censo2010.ibge.gov.br/

12. Santos RCS, Yamamoto YM, Custodio LMG. Aspectos teóricos sobre o processo de luto e a vivência do luto antecipatório. Psicologia.pt. 2018 [cited 2019 Mar 08]. Available from: http://www.psicologia.pt/artigos/textos/A1161.pdf 
13. Arrieira ICO, Thoferhn MB, Schaefer OM, Fonseca AD, Kantorski LP, Cardoso DH. The sense of spiritual care in the integrality of attention in palliative care. Rev Gaúcha Enferm. 2017;38(3):e58737. doi: https://doi.org/10.1590/19831447. 2017.03.58737

14. Vasconcelos EV, Freitas KO, Silva SED, Baia RSM, Tavares RS, Araújo JS. The daily life of relatives of patients admitted in icu: a study with social representations. J Res: Fundam Care Online 2016;8(2):4313-27. doi: https://doi.org/10.9789/21755361.2016.v8i2.4313-4327

15. Picollo D, Fachini ME. A atenção do enfermeiro ao paciente em cuidado paliativo. Rev Ciênc Méd. 2018;27(2):85-92. doi: https://doi. org/10.24220/2318-0897v27n2a3855

16. Carrias FMS, Souza GM, Pinheiro JDS, Lustosa MA, Pereira MCC, Guimarães $A E V$, et al. Visita humanizada em uma unidade de terapia intensiva: um olhar interdisciplinar. Tempus, Actas Saúde Colet. 2018 [cited 2019 Mar 10];11(2):103-12. Available from: https://www.tempusactas.unb.br/index. php/tempus/article/view/1966/1797

17. Dalpai D, Mendes FF, Asmar JAVN, Carvalho PL, Loro FL, Branco A. Pain and palliative care: the knowledge of medical students and the graduation gaps. Rev Dor. 2017;18(4):307-10. doi: https://doi.org/10.5935/1806-0013.20170120
18. Costa MR, Guimarães ITR, Baliza MF, Bouss ORS, Poles K. Moral suffering of nurses in end-of-life situations, in intensive therapy units. Revista de Enfermagem UFPE on line. 2017 [cited 2019 Sep 20];11(9 suppl):3607-16. Available from: https:// periodicos.ufpe.br/revistas/revistaenfermagem/article/download/234492/27694

19. Meneguin S, Nobukuni MC, Bravin SHM, Benichel CR, Matos TDS. 0 significado de conforto na perspectiva de familiares de pacientes em UTI. Rev Nurs. 2019 [cited 2019 Oct 11];22(252):2882-6. Available from: http://www. revistanursing.com.br/revistas/252/pg38.pdf

\section{Financial support:}

The present study was supported by the Coordination for the Improvement of Higher Education Personnel - Brazil (Coordenação de Aperfeiçoamento de Pessoal de Nivel Superior - Brasil - (APES) - Funding Code 001.

\section{Origin of the study:}

Perão, OF. Representações sociais do conforto para os familiares de pacientes adultos sob cuidados paliativos em unidade de terapia intensiva [thesis]. Florianópolis (SC): Universidade Federal de Santa Catarina; 2019.

\section{- Corresponding author:}

Odisséia Fátima Perão

Email: odisseiaperao@gmail.com

Associate editor:

\section{Editor-in-chief:}

Maria da Graça Oliveira Crossetti 